\title{
Integrated systems of agricultural production in the north of Mato Grosso and the physical properties of soil
}

\author{
Wellington de Azambuja MAGALHÃES ${ }^{1}$, Onã da Silva FREDDI ${ }^{2}$, Ricardo Santos Silva AMORIM ${ }^{3}$, \\ Vinicius MARCHIORO ${ }^{4}$, Luis Augusto Di Loreto DI RAIMO ${ }^{1}$, Flávio Jesus WRUCK 5
}

\author{
${ }^{1}$ Programa de Pós-Graduação em Agricultura Tropical, Universidade Federal de Mato Grosso, Cuiabá, MT, Brasil. \\ ${ }^{2}$ Instituto de Ciências Agrárias e Ambientais, Universidade Federal de Mato Grosso, Sinop, MT, Brasil. \\ ${ }^{3}$ Departamento de Solos e Engenharia, Faculdade de Agronomia e Zootecnia, Universidade Federal de Mato Grosso, Cuiabá, MT, Brasil \\ ${ }^{4}$ Programa de Pós-Graduação em Produção Vegetal, Universidade Estadual Paulista, Jaboticabal, SP, Brasil. \\ ${ }^{5}$ Embrapa Agrossilvipastoril, Sinop, MT, Brasil. \\ *E-mail: wellingtonagro@gmail.com
}

Recebido em janeiro/2018; Aceito em julho/2018.

\begin{abstract}
The areas with integrated agricultural production systems have increased considerably in recent years in Brazil. Thus, soil physical quality studies are essential in guiding the best management to be adopted, avoiding damages with the soil physical degradation. The aim of this study was to evaluate the physical properties of a Red Yellow Latosol under integrated production systems in the north of Mato Grosso after four years of implementation. The experiment was installed in January 2009 at the Technological Reference Unit (URT) of EMBRAPA Agrossilvipastoril at Fazenda Gamada, municipality of Nova Canaã do Norte, MT. The treatments consisted of five systems of crop-livestock-forestry integration (ICLF) in the following forestry arrangements: Eucalyptus in single line, double line and triple line (Eucalyptus I, II and III respectively), Teak in triple line and Pau-balsa in triple line. Soil samples with preserved structure were collected in the transverse direction of the forest species, to evaluate bulk density, soil resistance to penetration and soil porosity. There was higher bulk density in the ICLF systems with Teak and Pau-balsa. The penetration resistance of the soil was higher in the system with Teak in triple line. The trees density as well the forestry arrangements influence the soil physical properties. The integrated production systems with forest component Eucalyptus provided less physical degradation of the soil after four years of implantation. Regardless of the analyzed systems, the values of the physical properties in general indicated that the agricultural use of the soil associated with the history of the experimental area caused an increase of the restrictive effect to the root development of the cultures.
\end{abstract}

Keywords: bulk density, eucalyptus, soil physics, ICLF, Ochroma pyramidale, Tectona grandis.

\section{Sistemas integrados de produção agropecuária no norte de mato grosso e as propriedades físicas do solo}

\begin{abstract}
RESUMO: Áreas com sistemas integrados de produção agropecuária (SIPA) vêm aumentando consideravelmente nos últimos anos no Brasil. Com isso, estudos relativos à qualidade física do solo têm sido essenciais na orientação do melhor manejo a ser adotado evitando prejuízos com a degradação física do solo. Objetivou-se com este estudo avaliar as propriedades físicas de um Latossolo Vermelho Amarelo sob sistemas integrados de produção no norte de Mato Grosso após quatro anos de implantação. O experimento foi instalado em janeiro de 2009 na Unidade de Referência Tecnológica (URT) da EMBRAPA Agrossilvipastoril na Fazenda Gamada, município de Nova Canaã do Norte, MT. Os tratamentos consistiram de cinco sistemas de integração lavoura-pecuária-floresta (CLFI) nos seguintes arranjos florestais: Eucalipto em linha simples, linha dupla e linha tripla (Eucalipto I, II e III respectivamente), Teca em linha tripla e Pau-balsa em linha tripla. Amostras de solo com estrutura preservada foram coletadas na direção transversal das espécies florestais, para avaliação da densidade do solo, resistência do solo à penetração e porosidade do solo. Foi observada maior densidade do solo nos sistemas com Teca e Pau-balsa. A resistência à penetração do solo foi maior no sistema com teca em linha tripla. A densidade de árvores assim como os arranjos florestais influem sobre as propriedades físicas do solo. Os sistemas integrados de produção com componente florestal eucalipto proporcionaram menor degradação física do solo após quatro anos de implantação. Independentemente dos sistemas analisados, os valores das propriedades físicas, em geral, indicaram que o uso agrícola do solo associado ao histórico de uso da área experimental provocou aumento do efeito restritivo ao desenvolvimento radicular das culturas.
\end{abstract}

Palavras-chave: densidade do solo, eucalyptus, física do solo, ILPF, Ochroma pyramidale, Tectona grandis.

\section{INTRODUCTION}

The agricultural production systems undergo constant improvements in management in order to improve productivity without causing damage to the environment. These systems have expanded in Brazil and, in the 2015/16 harvest, represented an area of approximately 11.5 million 
hectares, about $5 \%$ of the total area under agricultural cultivation in the country (REDE ILPF, 2017).

The implantation of trees in the middle of agricultural and livestock areas has given rise to a new concept of an integrated system, the 'Agrossilvipastoril' or Crop-LivestockForestry Integration (CLFI) (BALBINO et al., 2012). The integrated systems with Forestry component represent an innovative advance in the integration issue and, according to Balbino et al. (2011), it is a strategy of sustainable production that integrates agriculture, livestock and forestry, carried out in the same area.

In the process of installation and conduction of the CLFI system, profound changes occur in the soil-plant dynamics, such as greater input of organic matter by plants and animal waste, greater nutrient cycling and less soil rotation (BALBINO et al., 2011). In this sense, several studies with soil microbiology, soil fertility, grass growth, tree density and soil physics have occurred in recent years within these systems (BENHUR et al., 2015a; BENHUR et al., 2015b; DIEL et al., 2014; SOUZA NETO et al., 2014; ASSIS et al., 2015; SILVA et al., 2016; NOGUEIRA et al., 2016; TONINI et al., 2016; STONE et al., 2015; STIEVEN et al., 2014; PACIULLO et al., 2011; OLIVEIRA et al., 2007). However, few studies directly address the action of these systems on soil physical properties, mainly in the inference of soil physical quality indicators.

The study of soil physical quality has been fundamental in the characterization of the systems and in the definition of the best management to be adopted. In the integrated systems of production with forest, the research has advanced in order to characterize the best productive arrangement. However, there is a great variability in the attributes due to the dynamics caused by the various factors that compose the system, such as: machinery, animals, trees, among others that integrate at different space-time scales (MORAES et al., 2014). Thus, undesirable changes can occur in soil structure leading to degradation and limiting the productive potential of these systems.

According to Assis et al. (2015), the crop-livestockforestry integration systems promote improvement in soil physical quality in relation to degraded pasture. In addition, these authors emphasize that the soil physical indicators vary according to the sampling position in relation to the Eucalyptus lines.

According to Souza Neto et al. (2014), the CLFI systems can be used for sustainability, and that long-term studies with these systems are needed to indicate better combinations of trees, grasses and cropping systems. Moraes et al. (2014) recalls the need for further studies in integrated systems to detect interactions among the various biotic and abiotic factors and new properties that emerge from these systems.

Although several studies are carried out in integration systems demonstrating their productive potential, information on the physical properties of the soil in different systems under different tree densities still demand greater understanding. The aim of this study was to evaluate the physical properties of a Red Yellow Latosol in different integrated production systems in the north of the State of Mato Grosso, after four years of implantation.

\section{MATERIAL AND METHODS}

The research was carried out at the Technological Reference Unit of the Brazilian Agricultural Research
Corporation (EMBRAPA-Agrossilvipastoril), Fazenda Gamada, municipality of Nova Canaã do Norte, MT, Brazil. According to the classification of Köppen, the region presents Awi type climate, tropical rainy, with clear dry season. The soil of the experimental area was classified according to SiBCS (SANTOS et al., 2013) as Dystrophic Red Yellow Latosol, corresponding to the Ferralsols according to FAO (WRB, 2014), with a sandy-clay soil texture, whose granulometric composition in the layer of 0 $0.20 \mathrm{~m}$ was $340 \pm 4.42 \mathrm{~g} \mathrm{~kg}^{-1}$ of clay and $540 \pm 4.72 \mathrm{~g} \mathrm{~kg}^{-1}$ of sand, and did not differ statistically between the evaluated areas.

The opening of the area was carried out in 1998 for the implementation of pasture with brachiaria, which remained for two years. The area was then used for annual crop cultivation for six consecutive years, two years cultivated with rice and four years with soybean crops 1 st harvest and corn crops 2 nd harvest. After this period, the crop was replaced by pasture, again with brachiaria, for another two years. In January 2009, the area was desiccated with glyphosate herbicide $\left(1.26 \mathrm{~kg} \mathrm{ha}^{-1}\right.$ of a.i.) and then furrows were opened for forest species planting, with a spacing of 20 $\mathrm{m}$ between rows for implantation of agricultural and livestock activities, where there was no mechanical soil preparation. The forest species were planted in the East-West direction to allow greater penetration of solar radiation between the rows.

The treatments consisted of five soil-use systems consisting of crop-livestock-forestry integration systems (CLFI), with different tree arrangements and densities, which are described in detail in Table 1.

The $20 \mathrm{~m}$ range between the tree rows was occupied by crop in the early years. In January 2009, the sowing of rice as 1st harvest was carried out, followed by the planting of brachiaria only as soil coverage. In the 2009/2010 harvest, the soybean was sown as 1 st harvest and rice in the 2 nd harvest. In the 2010/2011 harvest, there was sowing of soybeans in the 1 st harvest and corn in the 2 nd harvest. From March 2011, the pasture was introduced in the middle of the corn crop, which was grazed from June 2011. The average stocking rate of the area was 3.7 animals $\mathrm{ha}^{-1}$, with a gain of $1.04 \mathrm{~kg} \mathrm{day}^{-1}$ animal $^{-1}$, in the stages of rearing and finishing.

Tabela 1. Descrição dos sistemas integrados de produção, Nova Canaã do Norte-MT-Brasil.

Table 1. Description of integrated production systems, Nova Canaã do Norte-MT-Brazil.

\begin{tabular}{|c|c|}
\hline Sistema & Arranjo Florestal \\
\hline EUC-I & $\begin{array}{l}\text { Eucalyptus (Eucalyptus urograndis) in single } \\
\text { line: } 2 \mathrm{~m} \text { between trees and } 20 \mathrm{~m} \text { between } \\
\text { lines }\left(250 \text { trees }^{-1} \mathrm{~h}^{-1} \text {. }\right.\end{array}$ \\
\hline EUC-II & $\begin{array}{l}\text { Eucalyptus in double line: } 3 \mathrm{~m} \times 2 \mathrm{~m} \text { between } \\
\text { trees and } 20 \mathrm{~m} \text { between lines }\left(434 \text { trees ha }{ }^{-1}\right) \text {. }\end{array}$ \\
\hline EUC-III & $\begin{array}{l}\text { Eucalyptus in triple line: } 3 \mathrm{~m} \times 2 \mathrm{~m} \times 2 \mathrm{~m} \\
\text { between trees and } 20 \mathrm{~m} \text { between lines }(577 \\
\left.\text { trees } \mathrm{ha}^{-1}\right) \text {. }\end{array}$ \\
\hline TEAK & $\begin{array}{l}\text { Teak (Tectona grandis) in triple line: } 3 \mathrm{~m} \times 3 \\
\mathrm{~m} \times 2 \mathrm{~m} \text { between trees and } 20 \mathrm{~m} \text { between lines } \\
\left(577 \text { trees }^{-1}\right) \text {. }\end{array}$ \\
\hline P-BALSA & $\begin{array}{l}\text { Pau-balsa (Ochroma pyramidale) in triple line: } \\
3 \mathrm{~m} \times 3 \mathrm{~m} \times 2 \mathrm{~m} \text { between trees and } 20 \mathrm{~m} \\
\text { between lines }\left(577 \text { trees }^{-1}\right) \text {. }\end{array}$ \\
\hline
\end{tabular}


To evaluate the variability of soil physical properties under the different environments provided by the CLFI system, five sampling positions were considered within each treatment. The sampling positions were defined in the transversal direction to the forestry species lines being: at 10 $\mathrm{m}$ from the trees on the south side (10S), at 5 meters $(5 \mathrm{~S})$, at the center line under the trees $(0)$, and again on the north side at $5 \mathrm{~m}(5 \mathrm{~N})$ and at $10 \mathrm{~m}(10 \mathrm{~N})$, as Figure 1.

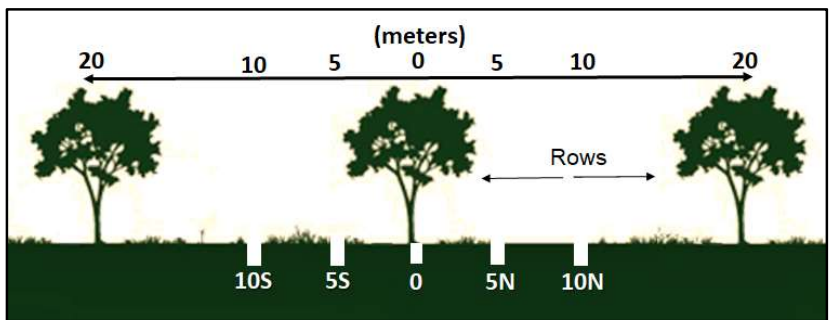

Figure 1. Sampling points in integrated production systems, Nova Canaã do Norte-MT, Brazil.

Figura 1. Pontos de amostragem nos sistemas integrados de produção, Nova Canaã do Norte-MT, Brasil.

In May 2013, an undisturbed sample was taken by sampling position in the $0-0.10 \mathrm{~m}$ and $0.10-0.20 \mathrm{~m}$ layers, considering three replications per production system, totaling 150 undisturbed samples. The undisturbed samples were obtained through metallic cylinders of $0.049 \mathrm{~m}$ of diameter and $0.05 \mathrm{~m}$ of height to determine bulk density (BD), soil resistance to penetration (RP), total porosity (TP), Macroporosity (Ma), Microporosity (Mi) and Cryptoporosity $(\mathrm{Cr})$.

The undisturbed samples were saturated through gradual elevation of a water level for $24 \mathrm{~h}$ and then submitted to the matric potential $(\Psi)$ of $0.01 \mathrm{MPa}$ and $1.5 \mathrm{MPa}$, applied to the tension table and Richards chamber, respectively. The volumetric moisture in each tension was calculated considering the bulk density of the treatments. After equilibrating the samples at each stress, their water contents were determined. After the samples were dried in an oven at $105^{\circ} \mathrm{C}$ for a period of 48 hours to determine bulk density and total porosity, using the method proposed by Embrapa (2011).The pore volume was determined by the matrix stresses that allow to classify the pores as a function of their diameter, being considered as Macropores, those with a diameter equal to or greater than $0.03 \mathrm{~mm}$, equivalent to a tension of $0.01 \mathrm{MPa}$; cryptopores from $1.5 \mathrm{Mpa}(<0.0002$ $\mathrm{mm}$ ); and micropores (pores with a diameter between 0.03 and $0.0002 \mathrm{~mm}$ ) determined by the difference between the tensions of 0.01 and $1.5 \mathrm{MPa}$ (Adapted from KLEIN, LIBARDI, 2002).

The PR was measured with a static electronic penetrometer with a constant penetration velocity of $10 \mathrm{~mm}$ $\mathrm{min}^{-1}$, a cone with a $30^{\circ}$ angle and a base area of $0.070 \mathrm{~cm}^{2}$. The readings were performed with the undisturbed samples whose water content was the remaining at the tension of 0.01 $\mathrm{MPa}$. The average PR was obtained from the 180 core values, with the first and last centimeter of the sample ends being neglected.

The BD was obtained by the relation between the weight of the soil by the volume of the cylinder. The relative bulk density (BDR) was determined on deformed samples collected in the $0-0.20 \mathrm{~m}$ layer and passed in $4 \mathrm{~mm}$ sieves. For this, the Proctor test was used with material reuse
(NOGUEIRA, 1998), according to the norms of ABNT-NBR 7182 (1986). The BDR was obtained by dividing the bulk density by the reference density and multiplied by 100 , being the result in percentage.

The averages were separated by the bootstrap technique, with 1000 random resampling with replacement, according to the method described by Christie (2004). This technique allows to estimate parameters of interest, such as average, variance, confidence intervals, among others. This technique is called a non-parametric bootstrap, since bootstrap estimates are based only on the data, and the probability distribution is not expected for this data (MELO FILHO et al., 2002; EFRON; TIBSSHIRANI, 1993). From the universe of 1.000 values, it was also possible to establish the upper and lower limits of the average confidence interval, at $95 \%$ probability, and this procedure was useful for later comparison of the means between them (MELLO et al., 2015). Thus, averages with common values within their confidence intervals, where the error bars meet do not differ from each other, whereas the absence of common values indicates a significant difference (at $5 \%$ probability) among them.

\section{RESULTS}

The BD presented significant difference among integrated production systems in both evaluated layers (Figure 2). The integrated systems in forestry arrangement with Teak and Pau-balsa presented the highest values of BD in the $0-0.10 \mathrm{~m}$ and $0.10-0.20 \mathrm{~m}$ layers in relation to the Eucalyptus systems. The lowest values of BD were observed in the systems with Eucalyptus in double line and triple line. There were no significant differences in BD between the soil sampling points in the different integrated production systems.

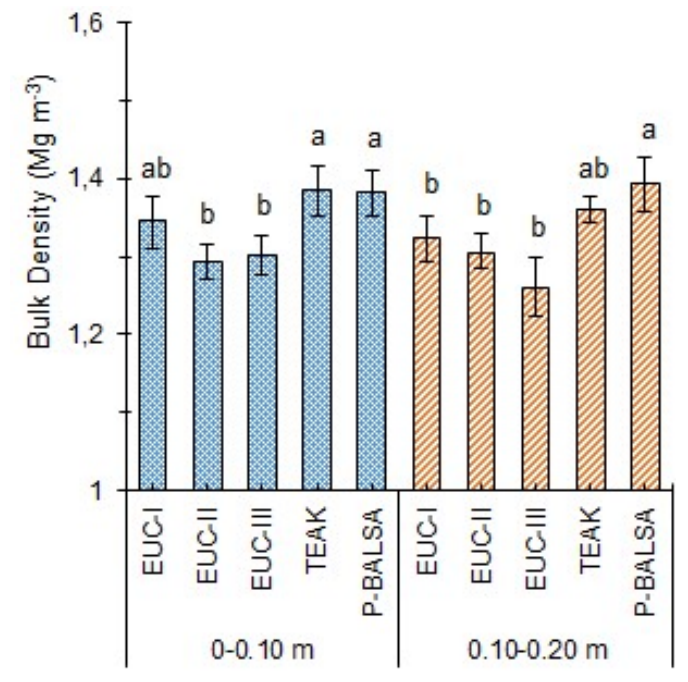

Figure 2. Bulk density in different integrated systems of agricultural production, Nova Canaã do Norte-MT-Brazil (EUC-I: single line; EUC-II: double line; EUC-III: triple line).

Figura 2. Densidade do solo em diferentes sistemas integrados de produção agropecuária, Nova Canaã do Norte-MT-Brasil (EUC-I: linha simples; EUC-II: linha dupla; EUC-III: linha tripla).

We determined the maximum soil compaction in the production systems using the Proctor test. The optimum compaction humidity as well as the maximum bulk density in the systems were respectively $0.19 \mathrm{~kg} \mathrm{~kg}^{-1}$ and $1.52 \mathrm{Mg} \mathrm{m}^{-3}$ 
in Eucalyptus single line; $0.22 \mathrm{~kg} \mathrm{~kg}^{-1}$ and $1.46 \mathrm{Mg} \mathrm{m}^{-3}$ in Eucalyptus double line; $0.20 \mathrm{~kg} \mathrm{~kg}^{-1}$ and $1.48 \mathrm{Mg} \mathrm{m}^{-3}$ in Eucalyptus triple line; $0.20 \mathrm{~kg} \mathrm{~kg}^{-1}$ and $1.51 \mathrm{Mg} \mathrm{m}^{-3}$ in Teak and; $0.17 \mathrm{~kg} \mathrm{~kg}^{-1}$ and $1.56 \mathrm{Mg} \mathrm{m}^{-3}$ in Pau-balsa .

The relative bulk density (BDR), corresponding to the relation between bulk density and maximum bulk density (SILVA et al., 2010) showed a significant difference in the 0.10-0.20 m layer (Figure 3). The lowest value of BDR was observed in the system with three Eucalyptus lines and the highest values of BDR in Eucalyptus systems in double line and Teak in triple line. The overall average was higher in the $0-0.10 \mathrm{~m}$ layer compared to the $0.10-0.20 \mathrm{~m}$ layer $(89.10 \%$ and $88.21 \%$, respectively).

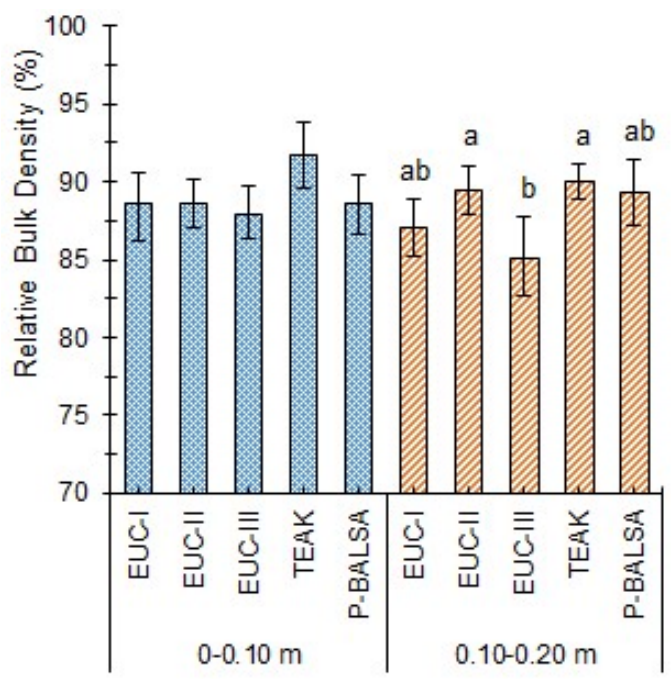

Figure 3. Relative bulk density in different integrated systems of agricultural production, Nova Canaã do Norte-MT-Brazil (EUC-I: single line; EUC-II: double line; EUC-III: triple line).

Figura 3. Densidade relativa do solo em diferentes sistemas integrados de produção agropecuária, Nova Canaã do Norte-MTBrasil (EUC-I: linha simples; EUC-II: linha dupla; EUC-III: linha tripla).

There was no significant difference between the integrated systems for the soil resistance to penetration (PR) in both layers evaluated, with an overall average of $5.13 \mathrm{MPa}$ and $3.54 \mathrm{MPa}$ respectively (Figure 4). The sampling sites also did not present significant differences among them in both analyzed layers.

The treatments with Eucalyptus, independently of the forestry arrangement, presented the highest values of PT in both layers, differing statistically from the treatments with Teak and Pau-balsa (Figure 5).

The porosity distribution in the macropore, micropores and cryptopores fraction for the $0-0.10$ and $0.10-0.20 \mathrm{~m}$ layers is described in Figure 6. The volume of macropores in the 0.10-0.20 m layer was higher in the Eucalyptus III system with $0.14 \mathrm{~m}^{3} \mathrm{~m}^{-3}$, differing statistically from the other treatments. In the $0.10-0.20 \mathrm{~m}$ layer, the microporosity was higher in the system with Pau-balsa and smaller under the systems with Eucalyptus I and III. However, for the 0-0.10 m layer there were no changes for this variable. The cryptopore volume in the $0-0.10 \mathrm{~m}$ layer and $0.10-0.20 \mathrm{~m}$ layer was lower in the Pau-balsa treatment.

The forestry arrangements consisting in Eucalyptus lines did not differ for most of the analyzed attributes, such as the $\mathrm{BD}$ in the $0-0.10 \mathrm{~m}$ layer (Figure 3), PR (Figure 4), TP
(Figure 5), macroporosity and microporosity in the $0-0.10 \mathrm{~m}$ layer and cryptoporosity in the 0.10-0.20 m layer (Figure 6).

Comparing the three-line arrangements consisting in Eucalyptus (EUC-III), Pau-balsa and Teak, a statistically significant difference was observed for BD in both layers, with the lowest values found in the forestry arrangement with Eucalyptus. For TP, again the statistical difference was observed in both layers, with the forestry arrangement with Eucalyptus presenting higher values.

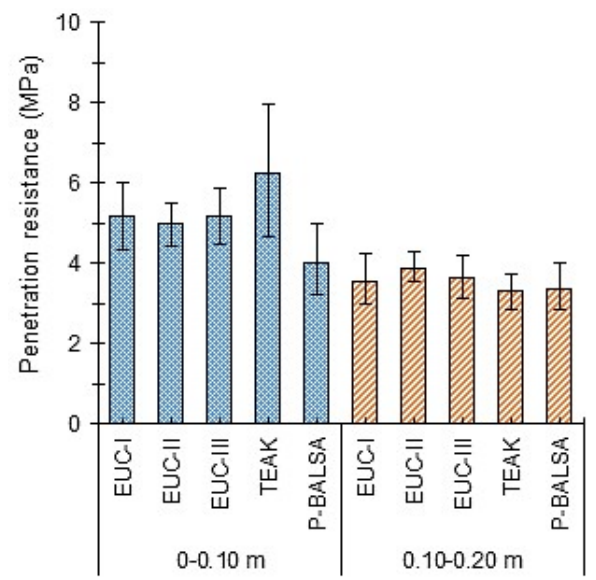

Figure 4. Penetration resistance of soil in different integrated systems of agricultural production, Nova Canaã do Norte-MT-Brazil (EUC-I: single line; EUC-II: double line; EUC-III: triple line).

Figura 4. Resistência do solo à penetração em diferentes sistemas integrados de produção agropecuária, Nova Canaã do Norte-MTBrasil (EUC-I: linha simples; EUC-II: linha dupla; EUC-III: linha tripla).

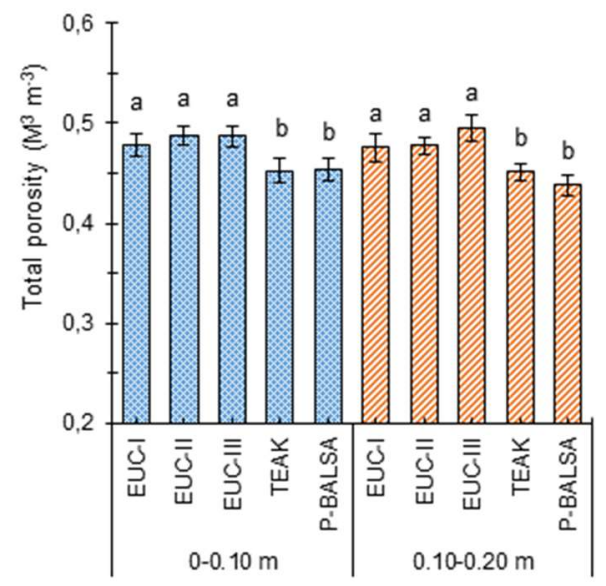

Figure 5. Total porosity of soil in different integrated systems of agricultural production, Nova Canaã do Norte-MT-Brazil (EUC-I: single line; EUC-II: double line; EUC-III: triple line).

Figura 5. Porosidade total do solo em diferentes sistemas integrados de produção agropecuária, Nova Canaã do Norte-MT-Brasil (EUCI: linha simples; EUC-II: linha dupla; EUC-III: linha tripla).

\section{DISCUSSION}

The highest values of BD were observed under the integrated systems with Teak and Pau-balsa. In these forestry arrangement in the triple-line, spaced at 20 meters between the forest rows promoted greater shading in relation to the Eucalyptus treatments. In this way, the lower development of the grass has made the soil more exposed to the animals trampling. Gobbi et al. (2009) observed an inversely proportional relation between the dry matter production of 
the brachiaria grass and the level of shading. According to Paciullo et al. (2011), the natural shading affects both the intensity and the quality of the incident radiation, promoting lower density of tillers, especially under intense shade conditions. In this way, the bad development of the grass, caused by the low photosynthetic radiation associated with the animals trampling, resulted in less physical protection of the soil in these systems.
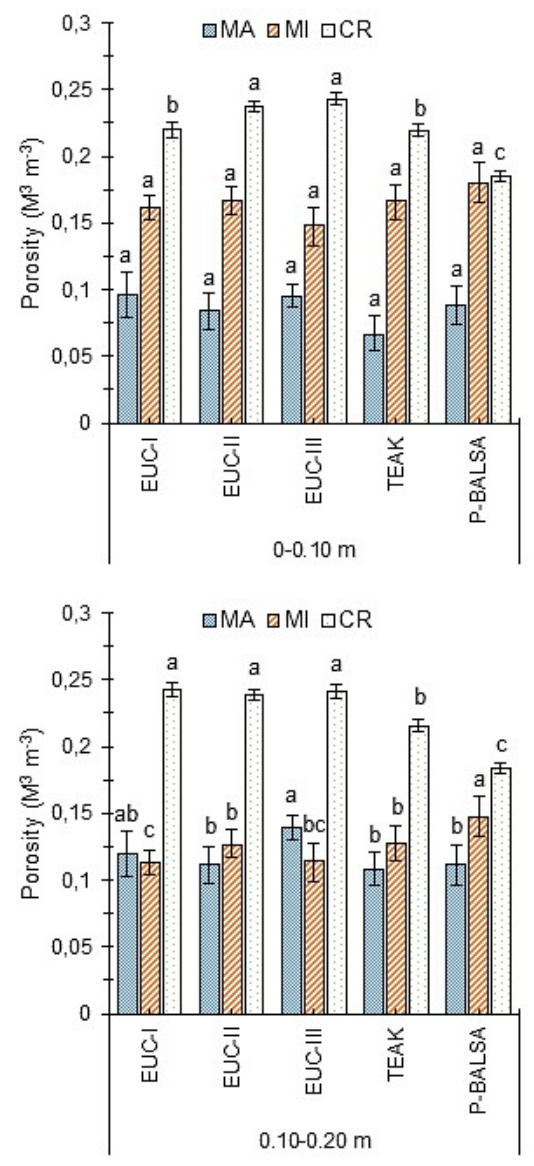

Figure 6. Volume of macropores (MA), micropores (MI) and criptopores (CR) in different integrated systems of agricultural production, Nova Canaã do Norte-MT-Brazil (EUC-I: single line; EUC-II: double line; EUC-III: triple line).

Figura 6. Volumes de macroporos (MA), microporos (MI) e criptoporos (CR) em diferentes sistemas integrados de produção agropecuária, Nova Canaã do Norte-MT-Brasil (EUC-I: linha simples; EUC-II: linha dupla; EUC-III: linha tripla).

For this study, there was no difference among the sampling sites for the variable BD. Souza Neto et al. (2014) and Paciullo et al. (2010) also found no differences for the BD variable in different sampling sites in relation to the Eucalyptus tree line grown in integrated systems.

In Proctor's essay, as soil moisture rises, bulk density also increases. This characteristic behavior occurs until a certain moment, since from certain moisture content the soil takes the water form (BUENO; VILAR, 1998). The ideal compaction moisture content represents the inadequate moment for agricultural operations with machinery, because under these conditions changes occur in the soil structure that will provide maximum compaction. According to Arvidsson; Håkanson, (1991), from the relative bulk density, it is possible to compare different soils quantitatively, minimizing the differences between them.

Several studies have been carried out in order to consider the optimum relative bulk density for the productivity or the maximum relative bulk density supported by the crops. Beutler et al. (2008) observed a decrease in yield of soybeans and maize with relative bulk density from 79 and $81 \%$, respectively. According to Lindstron; Voorhees (1994) values of BDR above $86 \%$ compromise root development for most crops. Thus, the average values of BDR found in this study can be considered as high and detrimental to crop development (Figure 3). Several factors may have corroborated for the high values of BDR in the treatments, among them the management practice in the systems. During the process of the treatments installation, there was no preparation of the soil, with only opening of furrows for the planting of forest species. In this way, it is assumed that the area was already compacted by the fact that it was being previously conducted with grazing in an extensive system. In addition, the cultural management of rice, soybeans and corn involved the use of machines for planting, desiccation, pest control and grain harvesting.

The PR values observed in all treatments (Figure 4) are above the values considered critical to the development of most agricultural crops that is $2.0 \mathrm{MPa}$ (TORMENA et al., 1998). According to Rosolem et al. (1999), values of 1.3 MPa of PR are sufficient to reduce the growth of the adventitious seminal roots of maize by $50 \%$.

The high PR values observed in the $0-0.10 \mathrm{~m}$ layer (Figure 4) can be attributed to the animals trampling over 24 months in the integrated systems. When evaluating the soil physical properties in a crop-livestock integration system, Lanzanova et al. (2007) verified that the soil compaction due to bovine trampling during three years of evaluation was limited to $0-0.10 \mathrm{~m}$. The higher bulk density in the subsurface layer is a result of previous tillage and plowing operations associated with animal trampling (SPERA et al., 2010; LANZANOVA et al., 2007).

Regarding the different sampling sites, the physical attributes (BD, BDR and PR) did not vary in the different environments provided by the integrated systems depending on the trees. Some studies also did not observe differences in the physical attributes of the soil with the distance of the trees rows in integrated production systems (PACIULLO et al., 2010; STONE et al., 2015; SOUZA NETO et al., 2014). It is presumed that this variation in attributes occurs very succinctly, even though some researchers have observed the preference for animals under the canopy of trees, possibly leading to soil disruption at these sites.

The values of total porosity measured in the integrated systems (Figure 5) are lower than those recommended in the literature as not limiting the development of the crops. According to Freddi et al. (2009), the macroporosity shows to be the most altered physical property by the compaction, being observed in this study, alterations in this variable in the $0-0.10$ and $0.10-0.20 \mathrm{~m}$ layer.

The values of macroporosity in the production systems, for both layers, did not present restrictions to the development of the plants according to Prevedello (1996). According to Leão (2002), the oxygen flow towards the plant root system is severely impaired when aeration porosity (macropores) is below $10 \mathrm{~m}^{3} \mathrm{~m}^{-3}$. The treatments with Paubalsa and Teak presented a lower Pt volume in the 0.10-0.20 
m layer (Figure 5), that can be attributed to the higher bulk density found in these systems. In this way, it is considered that after four years of integrated systems implantation, the planting of Teak and Pau-balsa in the configuration of triple lines $(3 \times 3 \times 3)$ spaced $20 \mathrm{~m}$ between rows contributes considerably to soil disruption in relation to systems with Eucalyptus in single, double and triple lines spaced $20 \mathrm{~m}$ in the rows.

\section{CONCLUSION}

After four years of implementation, the integrated systems of production under Eucalyptus promoted lower bulk density and higher porosity in relation to the systems with Teak and Pau-balsa.

The integrated systems with Teak and Pau-balsa in a triple line scheme spaced at $20 \mathrm{~m}$, provided greater soil physical degradation.

The cryptopore volume was lower in Teak and Pau-balsa systems.

There was no difference for the bulk density and relative bulk density variables in the different environments provided by the CLFI and their different arrangements and tree species.

The forestry arrangements constituted by Eucalyptus rows did not differ among themselves for $\mathrm{BD}$, Ma and $\mathrm{Mi}$, in the $0-0.10 \mathrm{~m}$ depth, PR and $\mathrm{Pt}$, in both layers, and $\mathrm{Cr}$ in the 0.10-0.20 m depth.

The triple line arrangements with Eucalyptus, Pau-balsa and Teak presented statistical differences between them for the attributes BD and TP, in both layers evaluated, being the lowest values of $\mathrm{BD}$ and higher of $\mathrm{TP}$ obtained for the forestry arrangement with Eucalyptus.

\section{ACKNOWLEDGMENTS}

The authors would like to thank the Foundation for Research Support of the State of Mato Grosso (FAPEMAT) (Fapemat/Cnpq - Pronem 2011 - Case n 477794/2011), for the financial support to the project. To Embrapa Agrossilvipastoril and Fazenda Gamada for the concession of the experimental area.

\section{REFERENCES}

ABNT ASSOCIAÇÃO BRASILEIRA DE NORMAS TÉC̄NICAS. NBR 7182: Solo - Ensaio de compactação. Rio de Janeiro, 1986.

ARVIDSSON, J.; HÅKANSSON, I. A Model for estimating crop yield losses caused by soil compaction. Soil \& Tillage Research, v. 20, n. 2-4, p. 319-332, 1991. DOI: https://doi.org/10.1016/0167-1987(91)90046-Z

ASSIS, P. C. R.; STONE, L. F.; MEDEIROS, J. C.; MADARI, B. E.; OLIVEIRA, J. M.; WRUCK, F. J. Atributos físicos do solo em sistemas de integração lavoura-pecuária-floresta. Revista Brasileira de Engenharia Agrícola e Ambiental, Campina Grande, v. 19, n. 4, p. 309-316, 2015.

BALBINO, L. C.; CORDEIRO, L. A. M.; OLIVEIRA, P.; KLUTHCOUSKI, J.; GALERANI, P. R.; VILELA, L. Agricultura sustentável por meio da integração lavourapecuaria-floresta (iLPF). International Plant Nutrition Institute, Piracicaba, v. 138, 2012.

BALBINO, L. C.; CORDEIRO, L. A. M.; PORFÍRIO-DASILVA, V.; MORAES, A.; MARTÍNEZ, G. B.; ALVARENGA, R. C.; KICHEL, A. N.; FONTANELI, R.
S.; SANTOS, H. P.; FRANCHINI, J. C.; GALERANI, P.R. Evolução tecnológica e arranjos produtivos de sistemas de integração lavoura-pecuária-floresta no Brasil. Pesquisa Agropecuária Brasileira, Brasília, v. 46, n. 10, p. 1-12, 2011. DOI: http://dx.doi.org/10.1590/S0100-204X2011001000001

BENHUR, S. O.; CARVALHO, M. A. C.; LANGE, A.; WRUCK, F. J.; DALLACORT, R. Atributos biológicos do solo em sistemas de integração lavoura-pecuáriafloresta, na região amazônica. Engenharia na Agricultura, Viçosa, v. 23, n. 5, p. 448-456, 2015. DOI: http://dx.doi.org/10.13083/1414-3984/reveng.v23n5p448456

BENHUR, S. O.; CARVAlHO, M. A. C.; LANGE, A.; DALLACORTE, R.; SILVA, V. P. Resistência do solo à penetração em áreas sob o sistema de integração lavourapecuária-floresta, na região amazônica. Enciclopédia Biosfera, Goiânia, v. 11, n. 22, p. 3678-3689, 2015.

BEUTLER, A. N.; FREDDI, O. S.; LEONE, C. L. \& CENTURION, J. F. Densidade do solo relativa e parâmetro "S" como indicadores da qualidade física para culturas anuais. Revista de Biologia e Ciências da Terra, São Cristóvão, v. 8, n. 2, p. 27-36, 2008.

BUENO, B. S.; VILAR, O. M. Mecânica dos solos. São Carlos: EESC-USP, 1998. p.131

CHRISTIE, D. Resampling with Excel. Teaching Statistics, Medford, v. 26, n. 1, p. 9-14, 2004. DOI: https://dx.doi.org/10.1111/j.1467-9639.2004.00136.x

DIEL, D.; BEHLING, M.; FARIAS NETO, A. L.; ISERNHAGEN, E. C. C. Distribuição horizontal e vertical de fósforo em sistemas de cultivos exclusivos de soja e de integração lavoura-pecuária-floresta. Pesquisa Agropecuária Brasileira, Brasília, v. 49, n. 8, p. 639647, 2014. DOI: http://dx.doi.org/10.1590/S0100204X2014000800008

EFRON, B.; TIBSHIRANI, R. J.; An introduction to the bootstrap. London: Chapman and Hall, 1993. 436p.

EMBRAPA_Empresa Brasileira de Pesquisa Agropecuária. Manual de métodos de análise de solo. Rio de Janeiro: Embrapa Solos, 2011. 230 p. (Documentos, 132)

FREDDI, O. S.; CENTURION, J. F.; DUARTE, A. P.; LEONEL, C. L. Compactação do solo e produção de cultivares de milho em Latossolo Vermelho. I Características de planta, solo e índice S. Revista Brasileira de Ciência do Solo, Viçosa, v. 33, n. 4, p. 793-803, 2009. DOI: http://dx.doi.org/10.1590/S010006832009000400005

GOBBI, K. F.; GARCIA, R.; GARCEZ NETO, A. F. Características morfológicas, estruturais e produtividade do capim-Braquiária e do amendoim forrageiro submetidos ao sombreamento. Revista Brasileira de Zootecnia, Viçosa, v. 38, n. 9, p. 1645-1654, 2009. DOI: http://dx.doi.org/10.1590/S1516-35982009000900002

KLEIN, V. A.; LIBARDI, P. L. Densidade e distribuição do diâmetro dos poros de um Latossolo Vermelho, sob diferentes sistemas de uso e manejo. Revista Brasileira de Ciência do Solo, Viçosa, v. 26, n. 4, p. 857-867, 2002. LANZANOVA, M. E.; NICOLOSO, R. S.; LOVATO, T.; ESTZ, F. L. F.; AMADO, T. J. C.; REINERT, D. J. Atributos físicos do solo em sistema de integração lavoura-pecuária sob plantio direto. Revista Brasileira de Ciência do Solo, Viçosa, v. 31, n. 5, p. 1131-1140, 
2007. DOI: http://dx.doi.org/10.1590/S010006832007000500028

LINDSTRON, M. J.; VOORHEES, W. B. Response of temperate crops to soil compaction. In: SOANE, B. D.; van OUWERKERK, C. (Ed.). Soil compaction in crop production. London: Elsevier, 1994. p. 265-286.

LEÃO, T. P. Intervalo hídrico ótimo em diferentes sistemas de pastejo e manejo da pastagem. 2002. $58 \mathrm{f}$. Dissertação (Mestrado em Agronomia) - Escola Superior de Agricultura "Luiz de Queiroz", Universidade de São Paulo, Piracicaba, 2002.

MELlO, J. M.; COUTO, E. G.; AMORIN, R. S. S.; JOHNSON, M. S.; LOBO, F. A. Dinâmica dos atributos físico-químicos e variação sazonal dos estoques de carbono no solo em diferentes fitofisionomias do pantanal norte mato-grossense. Revista Árvore, Brasília, v. 39, n. 2, p. 325-336, 2015. DOI: http://dx.doi.org/10.1590/010067622015000200012

MELO FILHO, J. F.; LIBARDI, P. L.; van LIER, Q. J.; CORRENTE, J. E. Método convencional e "bootsptrap" para estimar o número de observações na determinação dos parâmetros da função $\mathrm{K}(\Theta)$. Revista Brasileira de Ciência do Solo, Viçosa, v. 26, n. 4, p. 895-903, 2002. DOI: $\quad$ http://dx.doi.org/10.1590/S010006832002000400006

MORAES, A.; CARVALHO, P. C. F.; LUSTOSA, S. B. C.; LANG, C. R.; DEISS, L. A pesquisa em Sistemas Integrados de Produção Agropecuária no Brasil. Revista Ciência Agronômica, v. 45, n. 5, p. 1024-1031, 2014.

NOGUEIRA, J. B. Mecânica dos solos: ensaios de laboratório. São Carlos: USP/EESC, 1998.

NOGUEIRA, A. K. S.; RODRIGUES, R. A. R.; SILVA, J. J. N.; BOTIN, A. A.; SILVEIRA, J. G.; MOMBACH, M. A.; ARMACOLO, N. M.; ROMEIRO, S. O. Fluxos de óxido nitroso em sistema de integração lavoura-pecuáriafloresta. Pesquisa Agropecuária Brasileira, Brasília, v. 51, n. 9, p. 1156-1162, 2016. DOI: http://dx.doi.org/10.1590/s0100-204x2016000900015

OLIVEIRA, T. K.; MACEDO, R. L. G.; SANTOS, I. P. A.; HIGASHIKAWA, E. M.; VENTURIN, N. Produtividade de Braquiária brizantha (Hocht. ex. A. Rich) Stapf cv. Marandu sob diferentes arranjos estruturais de sistema agrossilvipastoril com eucalipto. Ciência e Agrotecnologia, Lavras, v. 31, n. 3, p. 748-757, 2007. DOI: $\quad$ http://dx.doi.org/10.1590/S141370542007000300022

PACIULlO, D. S. C.; CASTRO, C. R. T.; GOMIDE, C. A. M.; FERNANDES, P. B.; ROCHA, W. S. D.; MÜLLER, M. D.; ROSSIELlO, R. O. P. Soil bulk density and biomas partitioning of Brachiaria decumbens in a silvopastoral system. Scientia Agricola, Piracicaba, v. 67, n. 5, p. 598-603, 2010. DOI: http://dx.doi.org/10.1590/S0103-90162010000500014

PACIULlO, D. S. C.; GOMIDE, C. A. M.; CASTRO, C. R. T.; FERNANDES, P. B.; MÜLHER, M. D.; PIRES, M. F. A.; FERNANDES, E. N.; XAVIER, D. F. Características produtivas e nutricionais do pasto em sistema agrossilvipastoril, conforme a distância das árvores. Pesquisa Agropecuária Brasileira, Brasília, v. 46, n. 10, p. 1176-1183, 2011. DOI: http://dx.doi.org/10.1590/S0100-204X2011001000009

PREVEDELO, C. L. Física do solo com problemas resolvidos. Curitiba: SAEAFS, 1996. 446p.
REDE ILPF_INTEGRAÇÃO LAVOURA-PECUÁRIAFLORESTĀ. ILPF em números. Disponível em: $<$ https://www.embrapa.br/web/rede-ilpf/ilpf-emnumeros $>$. Acesso em: $11 \mathrm{dez} 2017$.

ROSOLEM, C.A.; FERNANDEZ, E.M.; ANDREOTTI, M.; CRUSCIOL, C.A.C. Crescimento radicular de plântulas de milho afetado pela resistência do solo à penetração. Pesquisa Agropecuária Brasileira, Brasília, v. 34, n. 5, p. 821-828, 1999. DOI: http://dx.doi.org/10.1590/S0100204X1999000500013

SANTOS, H. G. dos; JACOMINE, P. K. T.; ANJOS, L. H. C.; LUMBRERAS, J. F.; OLIVEIRA, J. B.; OLIVEIRA, V. A.; COELHO, M.R.; ALMEIDA, J. A.; CUNHA, T. J. F. Proposta de atualização da segunda edição do Sistema Brasileiro de Classificação de Solos: ano 2013. 2. ed. Rio de Janeiro: Embrapa Solos, 2013.

SILVA, A. P.; TORMENA, C. A.; DIAS JÚNIOR, M. S.; IMHOFF, S.; KLEIN, V. A. Indicadores da qualidade física do solo. In: van LIER, Q. J. (Ed.). Física do Solo. Viçosa: SBCS, 2010. p. 19-21.

SIlVA, A. R.; SAlES, A.; VEloso, C. A. C. Atributos físicos e disponibilidade de carbono do solo em sistemas de integração Lavoura-Pecuária-Floresta, Homogêneo e Santa Fé, no estado do Pará, Brasil. Revista Agropecuária Técnica, v. 37, n. 1, p. 96-104, 2016.

SOUZA NETO, E. L.; ANDRIOLI, I.; ALMEIDA, R. G.; MACEDO, M. C. M.; LAL, R. Physical quality of an oxisol under na integrated crop-livestock-forest system in the Brazilian Cerrado. Revista Brasileira de Ciência do Solo, Viçosa, v. 38, n. 2, p. 608-618, 2014. DOI: http://dx.doi.org/10.1590/S0100-06832014000200025

SPERA, S. T.; SANTOS, H. P.; FONTANELI, R. S.; TOMM, G. O. Atributos físicos de um Hapludox em função de sistemas de produção integração lavourapecuária (ILP), sob plantio direto. Acta Scientiarum, Maringá, v. 32, n. 1, p. 37-44, 2010. DOI: http://dx.doi.org/10.4025/actasciagron.v32i1.926

STIEVEN, A. C.; OLIVEIRA, D. A.; SANTOS, J. O.; WRUCK, F. J.; CAMPOS, D. T. Impacts of integrated crop-livestock-forest on microbiological indicators of soil. Revista Brasileira de Ciências Agrárias, Recife, v. 9, n. 1, p. 53-58, 2014. DOI: http://dx.doi.org/10.5039/agraria.v9i1a3525

STONE, L. F.; DIDONET, A. D.; ALCÂNTARA, F.; FERREIRA, E. P. B. Qualidade física de um Latossolo Vermelho ácrico sob sistemas silviagrícolas. Revista Brasileira de Engenharia Agrícola, Campina Grande, v. 19, n. 10, p. 953-960, 2015.

TONINI, H.; MORALES, M. M.; MENEGUCI, J. L. P.; ANTONIO, D. B. A.; WRUCK, F. J. Biomassa e área foliar de clones de eucalipto em ILPF: Implicações para a desrama. Revista Nativa, Sinop, v. 4, n. 5, p. 271-276, 2016. DOI: http://dx.doi.org/10.14583/23187670.v04n05a02

TORMENA, C. A.; SILVA, A. P.; LIBARDI, P. L. Caracterização do intervalo hídrico ótimo de um latossolo roxo sob plantio direto. Revista Brasileira de Ciência do Solo, Viçosa, v. 22, n. 4, p. 573-581, 1998. DOI: http://dx.doi.org/10.1590/S0100-06831998000400002

WRB_World Reference Base for Soil Resources. A framework for international classification, correlation and communication. Rome: IUSS/ISRIC/FAO, 2014. 145 p. (World Soil Resources Reports, 106). 